\title{
GOD, ELVISH, AND SECONDARY CREATION
}

\author{
ANDREW PINSENT \\ UNIVERSITY OF OXFORD
}

\begin{abstract}
According to the theological worldview of J. R. R. Tolkien, the principal work of a Christian is to know, love, and serve God. Why, then, did he devote so much time to creating an entire family of imaginary languages for imaginary peoples in an imaginary world? This paper argues that the stories of these peoples, with their 'eucatastrophes', have consoling value amid the incomplete stories of our own lives. But more fundamentally, secondary creation is proper to the adopted children of God and can be a way of drawing closer to God. Such work also witnesses to the freedom of the children of God, not only to receive salvation from God, but to contribute to the enrichment of creation and eternal life.
\end{abstract}

\section{THE PUZZLE OF USELESS CREATION}

Consider the following passage:

Ai! Laurië lantar lassi súrinen / Yéni únótimë ve rámar aldaron! Yéni ve lintë yuldar avánier / Mi oromardi lissë-miruvóreva / Andúnë pella, Vardo tellumar / Nu luini yassen tintilar i eleni / Ómaryo airetári-lírinen.

Ah! Like gold fall the leaves in the wind, / long years numberless as the wings of trees! / The years have passed like swift draughts / of the sweet mead in lofty halls beyond the West, / beneath the blue vaults of Varda / wherein the stars tremble in the song of her voice, holy and queenly. ${ }^{1}$

The text above is an example of Quenya, the language of the High Elves in Tolkien's legendarium, that is, the entirety of Tolkien's mythopoetic writings that form the background of his novels. The creation of Elvish, or rather several kinds of Elvish, contributed to the genesis of The Lord of the Rings, a story set in an imaginary world that become an unexpected tour de force of the

1 J. R. R. Tolkien, The Fellowship of the Ring (London: HarperCollins, 2011), 377-78. 
twentieth century. The author, John Ronald Reuel (J. R. R.) Tolkien, Professor of English Language and Literature at Merton College, Oxford, until his retirement in 1959, enjoyed creating languages. Thomas Nagel asked, "What is it like to be a bat?" Tolkien worked harder than most in trying to answer that question, inventing languages to fit the experiences, thought processes and cultures of extremely diverse, personal, corporal, non-human beings, from vicious monsters to talking trees. ${ }^{2}$

This tremendous creative labour raises some extremely puzzling questions from a theological perspective. Tolkien was a man of deep Christian faith and the aim of the life of faith is summed up in the succinct formula of The Penny Catechism of Tolkien's youth, "to know, love, and serve God, and to be happy with Him forever in Heaven."3 Since life is short, it would therefore seem prudent to devote a large part of one's leisure time, that is, time that is not allocated to the practical necessities of life, to these explicitly theological goals. But creating Elvish is painstaking, difficult, time-consuming, and useless. What, then, is the theological justification for spending so much time creating Elvish and an entire family of imaginary languages for imaginary peoples in an imaginary world? And if there is some positive good, from a theological perspective, in a human person creating a secondary world, what is that good and what does it tell us about God and the nature of God's action in the primary world?

These questions have implications that reach far beyond Tolkien's marvellous, idiosyncratic creation. The invention of Elvish seems an epitome of uselessness: it seemingly serves no goal beyond the satisfaction of its own creation. It is therefore a test case for useless arts generally and a way of addressing the following extremely important question. Is there a justification, within a theological worldview, of at least some creative but radically useless activities? And if there is no apologia for uselessness within theology, which at least defends the value of a wide diversity of goods, including immaterial goods, what justification is there for spending time on such matters in a world of pragmatic

2 Thomas Nagel, “What Is It Like to Be a Bat?", The Philosophical Review 83, no. 4 (1974). Some of Tolkien's most delightful creations come from consideration of such questions. Trees, for example, have a slow, upright, very long life, rooted in soil; hence the favourite motto of Tolkien's talking trees in The Lord of the Rings is, "Do not be hasty!" And their language is impossible for any other beings to learn in Tolkien's world, because it takes too long to say anything.

3 See, for example, Catholic Treasury, From the "Penny Catechism", accessed May 1, 2018, http://www.catholictreasury.info/catechism/cat1.php. 
materialism? Given that non-pragmatic activities are under pressure generally in many advanced societies today, the implications of any answers may also impact on the long-term survival of the humanities, the purely exploratory sciences, and arguably the university itself as noble, useless institution.

\section{KNOWING GOD AND EUCATASTROPHES}

In order to assess the goodness or otherwise of Tolkien's project, a prerequisite is to have some standard by which goodness can be assessed in the Christian life in general. Within Tolkien's worldview, as noted above, what is good may be described in formal terms as knowing, loving, and serving God; and a life of this kind has an end, namely being happy with God forever. But what does it mean to know, love, and serve God, and how might the creation of Elvish stand in relation to these goals?

At first, it might seem that the good, if there is any good, brought about by the development of Elvish and its associated legendarium must fall under the category of service, conveniently summarised in theology under the headings of the works of mercy. Works of mercy can be corporal, like the story of Martha serving lunch when Jesus visits her home (Luke 10:38-42), or spiritual, such as forming moral character or communicating theological ideas: an example is Jesus talking to Martha's sister Mary, who listens to him while Martha serves the lunch (Luke 10:39-40). On this basis, one might claim that, although Elvish itself is useless, it is part of a larger project of story-writing that has spiritual benefits. These stories contribute to forming moral character and communicating theological ideas, and hence contribute to instruction, one of the spiritual works of mercy. One might add that heroic stories tend to appeal to most people more readily than analytic presentations of ethics or systematic theology.

But this response raises a number of problems. Although Tolkien's work does edify and has even been claimed to have a sanctifying effect, ${ }^{4}$ Tolkien denied that he was writing allegories about our world, the primary world. Tolkien's work is one of secondary creation: a different world, a different history, different kinds of creatures, different languages, and dramas of salvation

4 Bradley J. Birzer and Joseph Pearce, J.R.R. Tolkien's Sanctifying Myth: Understanding Middle Earth (ISI Books, 2003). 
that differ in many details from our own. As one example, the elves, or some of them at least, have their own fall and salvation history. But this history is bound up wholly within the created order of nature and lacks any equivalent to the life of grace. ${ }^{5}$ As another example, revealed religion is more or less absent from Tolkien's world and most of the few references to worship involve worship of demonic beings. ${ }^{6}$ Tolkien's world is not simply our world in disguise, but a creation for its own sake, and much of the labour, especially the linguistic labour, has no obvious, or obviously apparent benefit for the works of mercy. And since Elvish seems to support neither the corporal nor the spiritual works of mercy, it can seem that time spent on Elvish can only be time diverted away from serving God and hence a waste. On this account, not only does the creation of Elvish fail to serve theological goals, but it actually detracts from such goals.

There are clearly imaginable situations in which a criticism of this kind carries some weight. If a person is called by God to some particular service, like Jonah being called to preach to Nineveh (Book of Jonah 1:2), then it is disobediently sinful to go and do something else, like taking a ship to some other, distant location (Jonah 1:3). Similarly, one could conceive of specific callings in which creating Elvish might a way to evade an activity willed explicitly by God, such as learning Chinese to preach the Gospel in China.

On the other hand, it is not easy to make a general case that any time that is not spent on works of mercy detracts from that service in the manner of a zero-sum game. The principal reason is that there is no straightforward relationship between time spent in God's service and the quality and fruits of that service. There are all kinds of interesting characters who are acknowledged as saints who spent very little of their time on works of mercy. An example is the 'good thief' crucified beside Jesus who did no more than acknowledge him and ask to be remembered by him "when you come into your kingdom," for which he was promised paradise that day and is still remembered today in this world as well (Luke 23:39-43). And the life of Jesus himself exhibits a curious pattern with respect to time, insofar as he did no overt and recorded

5 Drawing from the theological writings of Karl Rahner, who spoke of the anonymous Christian, elves might be described as an idealised, fictional Rahnerian species.

6 An example is the Temple built by Sauron during his time in Númenor and used for human sacrifice to the dark lord Morgoth, described in The Silmarillion: Akallabêth (The Downfall of Númenor). 
public work for thirty years. Presumably he worked much of that time as a carpenter (Mark 6:3), constructing things that served some immediate use but have long since rotted away. The key activity of his world-changing public ministry of less than three years took place over the last three days, with its climax over the last few hours. Hence, although time that is not spent on works of mercy might be wasted by some persons in some circumstances, it does not follow that all such time is wasted.

If the development of Elvish and its associated legendarium does not fall directly under the category of service, conveniently summarised under the headings of the works of mercy, what about the good of knowing and loving God? The general sense of Scripture, given iconic expression in the account of Martha and Mary noted previously, is that knowing and loving God is the primary good of the Christian life (Luke 10:41-42), upon which any fruitful works of mercy depend. But the prospects of Elvish contributing to this good do not seem promising for the reasons noted previously, namely that salvation history and revealed theology in a secondary world in general, and Tolkien's world in particular, differ in many respects from those of the primary world.

To make further progress, it is helpful to begin with the question of what is means to know God. In the Christian tradition, God is personal, and the challenge of knowing God can be regarded as a special case of the challenge of knowing a person. But knowing a person is a distinct achievement from knowing about a person. For example, one can collate vast numbers of facts about a person without having met that person. By contrast, knowing someone implies what Bertrand Russell called 'knowing by acquaintance,' in other words, first-person experience of a second person. ${ }^{7}$ And there are many other ways in which knowing and knowing about someone differ. For instance, we claim to know persons, but not facts about persons, by degree, qualifying claims to know someone by terms like 'well,' 'badly', 'slightly,' 'not at all', and so on. As another example to illustrate the difference, one can get to know a person quite well without necessarily knowing much about them or being able to express such knowledge. A prime example of the latter situation is that of prelinguistic infants, who begin to interact with other persons from a surpris-

7 The phrase "knowledge by acquaintance," distinguished from "knowledge by description," comes from Bertrand Russell, The Problems of Philosophy (Williams \& Norgate, 1912) See, for example, Russell, Problems of Philosophy, 109. 
ingly early age, and can be said to know particular persons, such as parents and caregivers, long before they can express that knowledge in propositions.

But first-person experience of a second person also needs to be finessed into two kinds of knowing by acquaintance. First, there is acquaintance with a person's presence as experienced by the senses, with the face and (to a lesser but still important extent) the voice playing a key role. Second, there is experience of a person's actions over extended time or, better still, interactions with that person over time. Given that the second kind of acquaintance involves experience with a person's characteristic ways of acting, it furnishes the best means to know character and the potential to form friendship.

In interactions of human persons, these modes of acquaintance are interwoven. A well-known example from infancy is the way that babies imitate facial expressions ${ }^{8}$ within minutes of being born, which manifests both a recognition of, and interest in, the human face coupled to the early desire to engage in imitative behaviour. Within their first year, infants are capable of engaging in gaze following, ${ }^{9}$ face-to-face interactions around patterns of attention contact ${ }^{10}$ and using gestures to engage in pre-verbal referential communication. ${ }^{11}$ These patterns of early pre-linguistic behaviour are presently classed and studied under the general category of 'joint attention', namely shared awareness of shared focus on some object of attention, gaining a shared stance towards that object. The relative lack of joint attention (sometimes called shared attention) is now recognized as one of the early signs of autistic spectrum disorder. ${ }^{12}$

8 Andrew N. Meltzoff and M. K. Moore, "Imitation of Facial and Manual Gestures by Human Neonates”, Science 198, no. 4312 (1977): 75-78.

9 G. Butterworth, "The Ontogeny and Phylogeny of Joint Visual Attention", in Natural Theories of Mind: Evolution, Development and Simulation of Everyday Mindreading, ed. Andrew Whiten (Blackwell, 1991), 223-32.

10 Colwyn Trevarthen, "Communication and Cooperation in Early Infancy: A Description of Primary Intersubjectivity", in Before Speech: The Beginning of Interpersonal Communication, ed. Margaret Bullowa (Cambridge Univ. Press, 1979).

11 Elizabeth Bates, Luigia Camaioni, and Virginia Volterra, "The Acquisition of Performatives Prior to Speech", Merrill-Palmer Quarterly of Behavior and Development 21, no. 3 (1975) See also Jerome Bruner and Rita Watson, Child's Talk: Learning to Use Language (Oxford Univ. Press, 1983) and Jerome Bruner, Carolyn Roy, and Nancy Ratner, “The Beginnings of Request", in Children's Language, ed. Keith E. Nelson (Lawrence Erlbaum Associates, 1978).

12 For a representative compilation of articles covering philosophical and psychological research in this area, see Naomi Eilan et al., Joint Attention: Communication and Other Minds (Clarendon Press, 2005). 
As children grow up and learn language, joint attention continues into complex play and the interweaving of life stories, leading in some cases to friendship. As Aristotle remarks:

Such (perfect) friendship requires time and familiarity; as the proverb says, men cannot know each other till they have 'eaten salt together'; nor can they admit each other to friendship or be friends till each has been found lovable and been trusted by each. Those who quickly show the marks of friendship to each other wish to be friends, but are not friends unless they both are lovable and know the fact; for a wish for friendship may arise quickly, but friendship does not (EN 8.4.156b26-32). ${ }^{13}$

Although Aristotle does not use the language of persons, which developed subsequently in a Christian context, it is notable that he underlines the necessity of time and familiarity to know someone and not merely to know about them. And this is common sense: we cannot know persons, certainly not to the point of trusting them, without experiencing how they act, which requires time and familiarity.

In the special case of God, the first kind of acquaintance (with a person's presence as experienced by the senses) does not happen in this life. But this absence does not preclude knowing God in the sense of becoming acquainted with God's extended actions over time. Indeed, a benefit of so much of Scripture being in the form of narratives is that one can come to know, at least at second hand, God, who is the principal personal agent depicted in Scripture. One can also come to know some of the persons closely associated with God who are described in Scripture. Peter, for example, is described in more detail than anyone else in the New Testament except Jesus Christ himself, and the careful reader can acquire a sense of what Peter would be like if one met him in the flesh. In other words, by means of these narratives, we can share, albeit at second hand, the experience of knowing these persons and their characters.

Moreover, the Christian life is also meant to involve coming to know God through interacting with God directly. Indeed, many claims about the Christian life can be understood in the light of growing into friendship with God in the life of grace, beginning in Baptism. For example, the operation of the gifts of the Holy Spirit, as Aquinas describes them, could be described as joint

13 Aristotle and Jonathan Barnes, Complete Works of Aristotle, Volume 2: The Revised Oxford Translation (Princeton Univ. Press, 2014), 1828. 
attention with God.' ${ }^{14}$ Although the focus of a Christian's attention should, at least part of the time, be on God and the things of God in prayer, a Christian should ideally be in a state of joint attention with God all the time, whether in prayer or attending to some other matter. In other words, in the ideal Christian life, all such attention should be aligned with God with a tacit awareness of the presence of God, at least at the edge of one's consciousness.

This joint attention with God is meant to have a twofold effect. First, a participation in God's stance that gives a new and specifically theological form to the virtues. With this attitude, for example, other human beings are not simply other rational animals, but potential or actual children of God. Second, this joint attention should draw us closer to God, if one permits oneself to be moved by God and hence aligned with God through the diversity of experiences that make up one's life. Most importantly, permitting oneself to be aligned with God over a long time can also lead to the harmonisation with God called divine friendship (caritas). Such friendship, at least in Scripture, is typically the fruit of a series of trials: Abraham is described as having become a friend of God after many trials (James 2:23); and Jesus describes his disciples as friends, but only at the Last Supper after they have spent years in his company and he has disclosed to them all that he has heard from the Father (John 15:15).

This joint attention with God can take anything, in principle, as its object. But holy stories are particularly potent because they are also one of the clearest ways of perceiving providential action. A paragon of this situation in Scripture is the account of the risen Jesus walking unrecognised beside two disciples and explaining how the Scriptures refer to himself (Luke 24:13-35). The disciples in this situation are coming to a deeper knowledge of God in two ways. First, they are becoming aligned with God incarnate walking beside them, though not yet recognised by them; second, they are also gaining a deeper understanding of God's providential action from new perspectives on ancient texts.

In principle, even one's own life story, as it is lived moment by moment, and viewed retrospectively can be a means of knowing God and God's providential action. But there is a challenge, namely that the stories of our lives are always incomplete in this world, a point to which Aristotle alludes in the Nicomachean Ethics:

14 This account is described in great detail in Summa Theologiae (ST) I-II, qq.55-70 and II-II, qq.1-170 and has been interpreted in terms of joint attention in Andrew Pinsent, The Second-Person Perspective in Aquinas's Ethics: Virtues and Gifts (Routledge, 2012), no. 2. 
For there is required, as we said, not only complete excellence but also a complete life, since many changes occur in life, and all manner of chances, and the most prosperous may fall into great misfortunes in old age, as is told of Priam in the Trojan Cycle; and one who has experienced such chances and has ended wretchedly no one calls happy (EN 1.9.1100a3-9).

In other words, we cannot assess happiness, or blessedness, until the story of a person's life is complete, which, in Christian theology, ends either in catastrophe, that is damnation, or what Tolkien calls 'eucatastrophe', namely sudden salvation from a terrible, impending, and probable doom.

And this eucatastrophe is what Tolkien calls the essence of fairy-stories,

The peculiar quality of the 'joy' in successful Fantasy can thus be explained as a sudden glimpse of the underlying reality of truth ... in the 'eucatastrophe' we see in a brief vision that the answer may be greater - it may be a far-off gleam or echo of evangelium in the real world. ${ }^{15}$

In this passage, Tolkien refers, in effect, to eucatastrophe as a point of commonality or consonance between successful fantasy and a theological perspective in this life. Moreover, he adds later that such stories have been hallowed by the Gospel, with the Birth of Christ as "the eucatastrophe of Man's history," and the Resurrection as "the eucatastrophe of the Incarnation."

Here there may be a first tentative answer to the value of Tolkien's work. Our own life stories are incomplete and will always stop short of the hopedfor eucatastrophe. In successful fantasy, although the salvation histories may differ in many details for those of the primary world, they do share in common the hoped-for eucatastrophe. Unlike our own lives, however, successful fantasy can take us up to the eucatastrophe, and even show a glimpse of what is beyond. And this glimpse of an end to the journey of life may at least serve as some encouragement to continue to walk a good path in this life. So one possible answer to the mystery of Tolkien's work that it is 'useful' after all, an encouragement to those of us who are still in a wayfarer state in this world and hence a spiritual work of mercy.

Without disputing this answer, however, it still fails to address the heart of the issue, namely whether there is an intrinsic value of secondary creation and how this creation stands in relation to a Christian life, beyond being a

15 J. R. R. Tolkien, On Fairy-Stories, ed. Verlyn Flieger and Douglas A. Anderson (HarperCollins, 2014), 77. 
means of encouragement. Some detailed questions may help to unpack the issue. If an ideal Christian life consists in harmonised joint attention with God with respect to the primary world, can one be in a state of joint attention with God with respect to a secondary world? What is the value of eucatastrophic stories in a secondary world, when there are already plenty of true stories that can be told about fruitful dramas in the primary world? And what is the value of so much labour expended on the details of the secondary world, especially, in Tolkien's case, a family of Elvish languages?

\section{IMPLICATIONS OF DIVINE FILIATION}

Much of the theological discussion of issues of providence and salvation tends to be conducted in rather formal, technical, and sombre terms, along the lines of how to reach a destination on a map, or a zero-sum game that attempts to attribute correctly the contributions of human and divine action. Hence it is worth thinking about aspects of the larger picture that can be obscured by this focus. One of these aspects is the teaching that Christians become adopted children of God in the life of grace.

Sin overshadows the innocence that is proper to the vocation to be divine children, but one catches a glimpse of what sinless human beings could be like very early on in the Book of Genesis, namely 2:19-20:

So out of the ground the LORD God formed every beast of the field and every bird of the air, and brought them to the man to see what he would call them; and whatever the man called every living creature, that was its name. The man gave names to all cattle, and to the birds of the air, and to every beast of the field (Revised Standard Version).

In this passage, the LORD God wants to see what the man will call the beasts (which, it should be noted, is a rather remarkable statement if everything is foreknown by God). The central activity is that the man attends to the beasts, and God attends to the man and to the beasts with the man. And in this context of this joint attention with God, man creates language.

There is something deeply innocent and playful about this situation. In the life of nature, children play and learn from play, but they also draw closer to one another and to their parents though play, often an intense form of joint attention. Why shouldn't there be a parallel for the life of grace? On this account, the creation of a secondary world may be taken as grandiose form of 
play, and if parents can draw closer to their children through play, why should God not draw closer to human beings through play, including the creation of secondary worlds and their languages? And if the LORD God drew close to Adam as he was creating language to describe mysterious new creatures in the primary world, it is plausible that one can be in a state of joint attention to God even when creating a language for elves.

But why bother with an intricate secondary world at all when there are so many edifying dramas to choose from in the primary world, and plenty of linguistic work to do as well? On this point, Tolkien has something to say on his own behalf:

I have claimed that Escape is one of the main functions of fairy-stories ... Why should a man be scorned if, finding himself in prison, he tries to get out and go home? Or if, when he cannot do so, he thinks and talks about other topics than jailers and prison-walls? ${ }^{16}$

In other words, as he elaborates further, Tolkien defends at least part of the value of fairy-stories as escape and recovery, a way of refreshing the spirit. And he goes on to suggest that good stories will change our mode of attention to the primary world as well:

Fantasy is made out of the Primary World, but a good craftsman loves his material, and has a knowledge and feeling for clay, stone and wood which only the art of making can give. By the forging of Gram cold iron was revealed; by the making of Pegasus horses were ennobled; in the Trees of the Sun and Moon root and stock, flower and fruit are manifested in glory. ${ }^{17}$

In other words, creative fantasy, using the primary world as its raw materials, can help to start attending to those materials in the world with a fresh and, perhaps, re-enchanted perspective. Even 'mere' materials like clay, stone, and wood, along with plants and animals, are not mere matter in motion but ennobled. Given, for example, God's description of interaction with the natural world in Job 38-41, this renewed perspective is plausibly closer to that of God than a trite and familiar gaze devoid of any sense of wonder. On this account, fantasy can help enhance the quality of our attention in the primary world in ways that may help us align more closely with God, refreshing jaded representations that distance us from reality.

16 Tolkien, On Fairy-Stories, 69.

17 Ibid., 68. 
And in response to the third question, especially about the detail devoted to the secondary world, it is plausible that a genuine child of God does God-like things, and the first exterior act of God is creation. And if detailed creation is what the Father does (though the Son, in union with the Spirit), surely we should expect the adopted children of God to do, and enjoy doing, likewise? Of course, in terms of power, human beings do not have the ability to create our own cosmoi and indeed, if we had that kind of power, it would almost certainly become destructive through human sinfulness. But the imaginative creation of secondary worlds in stories and associated languages is one way, and perhaps the only way, in which that kind of creativity can be exercised by human beings in the present reality.

\section{IMPLICATIONS FOR HUMAN FREEDOM}

The argument has often been made by philosophers and theologians in a modern age shaped by Cartesian science that there is no free will. But then what are we? Are we like parts of a machine, even if we are regarded like thinking tools, like slaves in the ancient world, or, more subtly, are our actions at least compatible with those of a deterministic cosmos? To the best of my belief and knowledge, there is no foolproof way of deciding these issues and people's opinions depend a great deal on the kinds of thought experiments that they choose to play in their imaginations. Our imaginations have been shaped by the useful but limited representations of Cartesian science, particularly mechanistic, two-body systems. Hence when simple, Libet-like experiments involving pushing buttons and so on are chosen for thought experiments, a story can be told that human beings are not free. In other words, when human beings are asked to perform mechanistic tasks, a machine-like story of human action can be told.

Consider, by contrast, Tolkien's far richer world of Elvish, along with his ents, dwarves, balrogs, and so on. Where do such creations come from? Are they the products of atoms interacting in Tolkien's brain? Or thoughts in the mind of God that Tolkien, without free will, was directed to transcribe? Or did Tolkien freely create such wild and wonderful beings, and does God delight in His children playing and rejoices in what they create? Cogs in machines do as they are made to do; they don't create. Only free children play games of creation, conjuring up secondary worlds that possess a consistency of reality. 
Hence the existence and creative depth of secondary worlds can serve as counterexamples to the cold depiction of unfree human wills like wheels set in tramlines. On this account, Tolkien's world can have a salutary effect in breaking the spells of some deadly illusions of certain philosophies, whose work, like that of the Ruling Ring in his great story, can trap us in a narrow and closed circle of ideas.

And besides their spell-breaking powers, Tolkien speculates that such secondary creations may add to the primary creation and its future glorification as well:

In God's kingdom, the presence of the greatest [story] does not depress the small. Redeemed Man is still man. Story, fantasy, still go on, and should go on. The Evangelium has not abrogated legends; it has hallowed them, especially the 'happy ending.' The Christian has still to work, with mind as well as body, to suffer, hope, and die; but he may now perceive that all his bents and faculties have a purpose, which can be redeemed. So great is the bounty with which he has been treated that he may now, perhaps, fairly dare to guess that in Fantasy he may actually assist in the effoliation and multiple enrichment of creation. ${ }^{18}$

In this passage, encouragement in the wayfarer state, in this world, is highlighted as a benefit of fantasy. But such work also witnesses to the freedom of the children of God, not only to receive salvation passively, but to contribute to the enrichment of creation and eternal life. If this perspective is correct, then secondary creations like Elvish and their associated stories are not mere instrumental means to refresh and encourage wayfarers but contribute to the form and quality of their final flourishing.

\section{BIBLIOGRAPHY}

Aristotle, and Jonathan Barnes. 2014. Complete Works of Aristotle, Volume 2: The Revised Oxford Translation. Princeton: Princeton Univ. Press.

Bates, Elizabeth, Luigia Camaioni, and Virginia Volterra. 1975. “The Acquisition of Performatives Prior to Speech”. Merrill-Palmer Quarterly of Behavior and Development 21, no. 3: 205-26.

Birzer, Bradley J., and Joseph Pearce. 2003. J.R.R. Tolkien's Sanctifying Myth: Understanding Middle Earth. Wilmington: ISI Books.

18 Ibid., 78-79. 
Bruner, Jerome, Carolyn Roy, and Nancy Ratner. 1978. "The Beginnings of Request”. In Children's Language, edited by Keith E. Nelson, 91-138. Hillsdale, NJ.: Lawrence Erlbaum Associates.

Bruner, Jerome, and Rita Watson. 1983. Child's Talk: Learning to Use Language. Oxford: Oxford Univ. Press.

Butterworth, G. 1991. "The Ontogeny and Phylogeny of Joint Visual Attention". In Natural Theories of Mind: Evolution, Development and Simulation of Everyday Mindreading, edited by Andrew Whiten, 223-32. Oxford: Blackwell.

Catholic Treasury. From the "Penny Catechism". Accessed May 1, 2018. http://www. catholictreasury.info/catechism/cat1.php.

Eilan, Naomi, Christoph Hoerl, Teresa McCormack, and Johannes Roessler. 2005. Joint Attention: Communication and Other Minds. Oxford: Clarendon Press.

Meltzoff, Andrew N., and M. K. Moore. 1977. "Imitation of Facial and Manual Gestures by Human Neonates". Science 198, no. 4312: 75-78.

Nagel, Thomas. 1974. "What Is It Like to Be a Bat?". The Philosophical Review 83, no. 4: 435. doi:10.2307/2183914.

Pinsent, Andrew. 2012. The Second-Person Perspective in Aquinas's Ethics: Virtues and Gifts. New York: Routledge.

Russell, Bertrand. 1912. The Problems of Philosophy. London: Williams \& Norgate. Tolkien, J. R. R.. 2011. The Fellowship of the Ring, New edition. London: HarperCollins -. 2014. On Fairy-Stories. Expanded ed., with commentary and notes. Edited by Verlyn Flieger and Douglas A. Anderson. London: HarperCollins.

Trevarthen, Colwyn. 1979. "Communication and Cooperation in Early Infancy: A Description of Primary Intersubjectivity". In Before Speech: The Beginning of Interpersonal Communication, edited by Margaret Bullowa, 321-72. Cambridge: Cambridge Univ. Press. 